\title{
Demokrasi dan Legalitas Mantan Narapidana dalam Pemilihan Kepala Daerah dan Pemilihan Umum
}

\author{
Muhammad Anwar Tanjung dan Retno Saraswati \\ Fakultas Hukum Universitas Diponegoro \\ Jl. Imam Bardjo SH No.1, Pleburan, Semarang, Jawa Tengah 50241 \\ 99tanjunganwar@gmail.com; saraswatiretno@yahoo.co.id
}

Received: 3 Mei 2018; Accepted: 13 Agustus 2018; Published: 5 Nopember 2018

DOI: 10.20885/iustum.vol25.iss2.art9

\begin{abstract}
The focus of this study was on the decision of the Constitutional Court number 4/PUU-VII/2009 and decision number 14-17/PUU-V/2007 which legitimize former prisoners as regional head and legislative candidates. This study aimed to analyze the legality of former prisoners to participate in an election and the efforts to be made after the Constitutional Court's decisions in terms of building democracy in Indonesia. This study used normative research method with statute and conceptual approaches. The results of this study concluded that first, a former prisoner has constitutional right as a candidate in an election that is a part of non-derogable rights except by a court decision that has permanent legal force. Some efforts to build democracy are made by issuing regulations that technically explain the decisions of the Constitutional Court for former prisoners who will participate in an election as well as severe sanctions for the violations, and involving the supervision of election organizing committee in the nomination process.
\end{abstract}

Keywords: Democracy; former prisoners; local election; general election

\section{Abstrak}

Fokus kajian penelitan ini adalah putusan Mahkamah Konstitusi Nomor 4/PUU-VII/2009 dan putusan nomor 14-17/PUU-V/2007 yang melegitimasi mantan narapidana sebagai calon kepala daerah dan calon legislatif. Penelitian ini bertujuan untuk menganalisis legalitas mantan narapidana untuk turut serta dalam pemilihan berikut upaya yang dilakukan pasca putusan Mahkamah Konstitusi dalam kerangka membangun demokrasi di Indonesia. Kajian ini menggunakan metode penelitian normatif dengan menggunakan pendekatan perundang-undangan dan konsep. Hasil kajian ini menyimpulkan bahwa pertama, seorang mantan narapidana memiliki hak konstitusional sebagai calon dalam pemilihan yang tidak dapat dikurangi dengan alasan apapun kecuali oleh putusan pengadilan yang telah berkekuatan hukum tetap. Upaya membangun demokrasi dilakukan dengan mengeluarkan peraturan yang menjabarkan secara teknis putusan Mahkamah Konstitusi bagi mantan narapidana yang akan turut serta dalam pemilihan disertai dengan sanksi berat bagi pelanggarnya serta melibatkan pengawasan lembaga penyelenggara pemilu pada proses pencalonan tersebut.

Kata-kata Kunci: Demokrasi; mantan narapidana; pemilihan kepala daerah; pemilihan umum 


\section{Pendahuluan}

Pasal 1 ayat (2) UUD 1945 menyatakan bahwa kedaulatan berada di tangan rakyat dan dilaksanakan menurut ketentuan Undang-Undang Dasar. Pasal 1 ayat (3) UUD 1945 menyatakan bahwa negara Indonesia adalah negara hukum. ${ }^{1}$ Berdasarkan rumusan pasal tersebut jelas bahwa negara Indonesia wajib menjamin terlaksananya sebuah pemilihan umum yang bebas tanpa terkecuali, sebagai bukti bahwa Indonesia merupakan negara hukum. Pada konteks ini pemilihan kepala daerah dan pemilihan umum berada pada dimensi hukum sebagai wujud hak asasi manusia. ${ }^{2}$ Adanya prinsip persamaan di muka hukum harus diartikan ketidakberpihakan terhadap setiap warga masyarakat di mata hukum sehingga dapat dituntut dengan derajat yang sama tanpa membeda-bedakannya. ${ }^{3}$

Hak Asasi Manusia (HAM) merupakan hak hukum yang berusaha menerjemahkan keyakinan tentang martabat manusia ke dalam bahasa hukum yang konkret dengan tujuan agar hak-hak itu seperlunya dapat dipaksakan pelaksanaanya di depan pengadilan. ${ }^{4}$ Konsepsi HAM dalam perkembangannya sangat terikat dengan konsepsi negara hukum. Dalam sebuah negara hukum sesungguhnya yang memerintah adalah hukum, bukan manusia. Hukum dimaknai sebagai kesatuan hirarkis tatanan norma hukum yang berpuncak pada konstitusi. Hal ini berarti bahwa dalam sebuah negara hukum menghendaki adanya supremasi konstitusi. Supremasi konstitusi di samping merupakan konsekuensi dari konsep negara hukum sekaligus merupakan pelaksanaan demokrasi karena konstitusi merupakan wujud perjanjian sosial tertinggi. ${ }^{5}$

Pemilihan umum juga tidak hanya berkaitan dengan kebutuhan pemerintah akan keabsahan kekuasaannya tetapi juga sebagai sarana rakyat mengartikulasikan

${ }^{1}$ Jimly Asshiddiqie, Gagasan Kedaulatan Rakyat Dalam Konstitusi Dan Pelaksanaannya Di Indonesia, PT Ichtiar Baru Van Hoeve, Jakarta, 1994, hlm. 59 - 105.

${ }^{2}$ Rahayu, Hukum Hak Asasi Manusia, Edisi Revisi, Badan Penerbit Universitas Diponegoro, Semarang, 2015, hlm. 1. hlm. 5-7.

3 Topo Santoso dan Eva Achjani Zulfa, Kriminologi, Jakarta, Rajawali Pers, 2003, hlm. 5 lihat juga Ahmad Ulil Aedi, "Rekonstruksi Asas Kesamaan di Hadapan Hukum (Equality Before The Law) (Suatu Kajian Khusus Putusan Mahkamah Konstitusi Perkara 21-22/PUU-V/2007 Dalam Perspektif Filsafat Hukum”, artikel dalam Jurnal Law Reform, Vol. 8, No. 2, Tahun 2013, hlm. 1

${ }^{4}$ Franz Magnis-Suseno, Etika Politik, Gramedia Pustaka Utama, Jakarta, 2001, hlm. 135. $152-162$

${ }_{5}^{5}$ Jimly Asshiddiqie, Konstitusi \& Konstitusionalisme Indonesia, Edisi Revisi, Konstitusi Press, Jakarta, 2005, hlm. 
aspirasi dan kepentingan dalam kehidupan berbangsa dan bernegara. ${ }^{6}$ Legalitas mantan narapidana sebagai kandidat yang akan turut serta dalam pemilihan kepala daerah dan pemilihan umum sensitif dibicarakan. Iktikad baik lembaga penyelenggara pemilu dalam menghasilkan calon terbaik dalam pemilihan kepala daerah dan pemilihan umum harus didukung. Iktikad baik tersebut harus memperhatikan sumber hukum yang berlaku demi tujuan hukum yakni keadilan, kemanfaatan dan kepastian hukum. Untuk itu paper ini akan membahas legalitas mantan narapidana sebagai kandidat dalam pemilihan kepala daerah dan pemilihan umum. Legalitas narapidana sebagai kandidat tidak terlepas dari putusan Mahkamah Konstitusi yang dalam beberapa putusannya bersifat constitusional bersyarat terhadap kandidat yang pernah dinyatakan bersalah melalui putusan pengadilan yang berkekuatan hukum tetap.

KPU sebagai lembaga penyelenggara pemilu pada April 2018 menyampaikan keinginanannya untuk melarang mantan terpidana korupsi jadi bakal caleg DPR dan DPRD.7 Pro dan kontra terhadap persoalan ini muncul di kalangan pemerhati pemilu, partai politik, akademisi dan lapisan masyarakat.

\section{Rumusan Masalah}

Berdasarkan penjelasan di atas, maka permasalahan yang dibahas dalam tulisan ini adalah bagaimana memahami legalitas mantan narapidana dalam pemilihan kepala daerah dan pemilihan umum berikut upaya yang dilakukan pasca putusan Mahkamah Konstitusi dalam kerangka membangun demokrasi di Indonesia?

\section{Tujuan Penelitian}

Penelitian bertujuan untuk menganalisis legalitas mantan narapidana dalam pemilihan kepala daerah dan pemilihan umum dalam putusan Mahkamah Konstitusi berikut upaya yang harus dilakukan oleh penyelenggara pemilu pasca

\footnotetext{
${ }^{6}$ Affan Sulaeman, "Demokrasi, Partai Politik, Dan Pemilihan Kepala", artikel dalam Jurnal Ilmu Pemerintahan D CosmoGov, Vol.1 No.1, April 2015, hlm. 20

${ }^{7}$ Dylan Aprialdo Rachman, "KPU Tidak Perlu Mundur Soal Larangan Mantan Koruptor Jadi Caleg 2019" https://nasional.kompas.com/read/2018/04/17/11333141/kpu-tidak-perlu-mundur-soal-larangan-mantankoruptor-jadi-caleg-2019 di akses tanggal 24 April 2018.
} 
putusan tersebut dalam rangka tetap melaksanakan nilai-nilai demokrasi dan prinsip penyelenggaraan pemilu yang demokratis di Indonesia.

\section{Metode Penelitian}

Penelitian ini merupakan penelitian normatif. Penelitian hukum ini dikonsepkan sebagai apa yang tertulis dalam peraturan perundang-undangan (law in books) atau hukum dikonsepkan sebagai kaidah atau norma yang merupakan patokan berperilaku manusia yang dianggap pantas. ${ }^{8}$ Dalam penelitian ini bahan hukum yang menjadi rujukan adalah bahan hukum sekunder yang didukung oleh bahan hukum primer dan menggunakan pendekatan perundang-undangan (statute approch) dan pendekatan konsep (conceptual approch) serta analisis bahan dilakukan secara deskriptif analisis.

\section{Hasil Penelitian dan Pembahasan}

\section{Analisis Yuridis Legalitas Mantan Narapidana Dalam Pemilihan Kepala Daerah dan Pemilihan Umum}

Pancasila sebagai dasar Negara Republik Indonesia menyatakan dalam sila kelima keadilan sosial bagi seluruh rakyat Indonesia. Sila ini bermakna tidak boleh ada perlakuan diskriminatif bagi seluruh anak bangsa dalam seluruh bidang kehidupan terkecuali dipersyaratkan lain oleh undang-undang atau putusan hakim. Pelaksanaan hal tersebut diwujudkan dalam pasal 27 ayat (1) UUD 1945 menyatakan hak atas kesamaan kedudukan dalam hukum dan pemerintahan yang tidak ada kecualinya. Pasal 28D ayat (3) UUD 1945 menyatakan hak untuk memperoleh kesempatan yang sama dalam pemerintahan. Berdasarkan hal tersebut menyatakan pemberlakukan diskriminasi terhadap warga negara merupakan perbuatan yang dilarang oleh konstitusi.

Putusan Mahkamah Konstitusi Nomor 14-17/PUU-V/2007 tanggal 11 Desember 2007 dalam amar putusannya telah menolak permohonan pengujian Pasal 58 huruf f Undang-Undang Nomor 32 Tahun 2004 tentang Pemerintahan Daerah, Pasal 6 huruf $t$ Undang-Undang Nomor 23 Tahun 2003 tentang Pemilihan Umum Presiden dan Wakil Presiden, Pasal 16 ayat (1) huruf d Undang-Undang

${ }^{8}$ Amiruddin dan Zainal Asikin, Pengantar Metode Penelitian Hukum, Rajawali Pers, Jakarta, 2014, hlm. 118. 
Mahkamah Konstitusi, Pasal 7 ayat (2) huruf d Undang-Undang Nomor 5 Tahun 2004 tentang Perubahan Atas Undang-Undang Nomor 14 Tahun 1985 tentang Mahkamah Agung, dan Pasal 13 huruf g Undang-Undang Nomor 16 Tahun 2006 tentang Badan Pemeriksa Keuangan yang kesemuanya menguji syarat "tidak pernah dijatuhi pidana dengan pidana penjara berdasarkan putusan pengadilan yang telah mempunyai kekuatan hukum tetap karena melakukan tindak pidana yang diancam dengan pidana penjara 5 tahun atau lebih". Dalam pertimbangan putusan tersebut dinyatakan pasal-pasal berbagai undang-undang yang diuji dinyatakan sebagai konstitusional bersyarat (conditionally constitutional), yakni dikecualikan untuk tindak pidana yang bersifat kealpaan ringan (culpa levis) dan tindak pidana karena alasan perbedaan pandangan politik.

Hal yang menjadi pertimbangan dalam putusan ini menyangkut kekhususankekhususan karakter jabatan-jabatan publik tertentu menyebabkan tidak semua jabatan publik dapat ditentukan persyaratan dengan menggunakan rumusan norma yang bersifat umum sehingga perlu pembedaan persyaratan antara lain:

1. Jabatan publik yang dipilih (elected officials) dan jabatan publik yang diangkat (appointed officials);

2. Jabatan publik di bidang eksekutif yang lebih bersifat melayani dan jabatan publik di bidang legislatif yang bersifat menyalurkan aspirasi rakyat; dan

3. Jabatan publik yang karena tugasnya membutuhkan tingkat kepercayaan yang sangat tinggi, seperti hakim dan aparat penegak hukum lainnya, dan pejabat yang mengelola keuangan negara.

Pertimbangan sosiologis dan historis Mahkamah Konstitusi dalam memutus perkara ini yakni kebijakan amnesti terhadap para anggota PRRI/Permesta dan GAM yang pada waktu itu juga telah melakukan tindak pidana yang cukup berat ancaman hukumannya menurut hukum positif Indonesia. Pihak yang terlibat dalam pemberontakan G.30.S/PKI yang persyaratan tidak terlibat secara langsung atau tidak langsung agar dapat menjadi calon anggota DPR, DPD, dan DPRD telah dinyatakan tidak konstitusional oleh Mahkamah melalui putusan Nomor 1117/PUU-I/2003 tanggal 24 Februari 2004. 
Norma hukum dalam putusan a quo tersebut adalah inkonstitusional apabila tidak dipenuhi syarat-syarat sebagai berikut: ${ }^{9}$

1. Berlaku bukan untuk jabatan-jabatan publik yang dipilih (elected officials) sepanjang tidak dijatuhi pidana tambahan berupa pencabutan hak pilih oleh putusan pengadilan yang telah mempunyai kekuatan hukum tetap;

2. Berlaku terbatas untuk jangka waktu 5 (lima) tahun setelah mantan terpidana selesai menjalani pidana penjara berdasarkan putusan pengadilan yang telah mempunyai kekuatan hukum tetap;

3. Kejujuran atau keterbukaan mengenai latar belakang jati dirinya sebagai mantan terpidana;

4. Bukan sebagai pelaku kejahatan yang berulang-ulang;

Tidak pernah dijatuhi pidana penjara berdasarkan putusan pengadilan yang telah mempunyai kekuatan hukum tetap karena melakukan tindak pidana yang diancam pidana penjara 5 tahun atau lebih", jika diberlakukan tanpa syarat-syarat tertentu dapat menegasi prinsip persamaan kedudukan dalam hukum dan pemerintahan serta melanggar hak seseorang atau warga negara atas perlakuan, jaminan, perlindungan, dan kepastian hukum yang adil, serta perlakuan yang sama di hadapan hukum, dan hak memperoleh kesempatan yang sama dalam pemerintahan yang pada hakikatnya merupakan moralitas hukum dan moralitas konstitusi. Membaca putusan a quo harus merupakan satu kesatuan yang harus dipenuhi secara keseluruhan. Bilamana satu dari ketentuan tidak dipenuhi maka seorang mantan narapidana tidak berhak sebagai calon kandidat dalam pemilihan kepala daerah dan pemilihan umum.

Peneliti menggunakan konsep hukum progresif untuk menghasilkan konsep baru terhadap suatu persoalan perlu pemikiran bebas dan berani keluar dari status quo. Progresif berasal dari kata progress yang berarti kemajuan. Hukum hendaknya mampu mengikuti perkembangan zaman, mampu menjawab perubahan zaman, dengan segala dasar di dalamnya, serta mampu melayani masyarakat dengan menyandarkan pada aspek moralitas dan sumber daya manusia penegak hukum itu sendiri. ${ }^{10}$ Hukum pemilu harus mampu dan cepat merespon perubahan masyarakat yang terjadi. Memaksakan hukum pemilu terus berlaku membuat daya laku hukum tidak efektif. Atau memaksakan hukum

\footnotetext{
${ }_{9}$ Putusan Mahkamah Konstitusi Nomor 14-17/PUU-V/2007 tanggal 11 Desember 2007

${ }^{10}$ Satjipto Rahardjo, Membedah Hukum Progresif, Penerbit Buku Kompas, 2008, hlm. ix.
} 
pemilu kepada masyarakat atau condong melakukan penegakan hukum melahirkan penolakan bahkan konflik di masyarakat.

Gagasan hukum progresif dimulai dari asumsi dasar filosofis bahwa hukum adalah untuk manusia bukan sebaliknya. Dengan demikian, keberadaan hukum adalah untuk melayani dan melindungi manusia bukan sebaliknya. Hukum dianggap sebagai institusi yang bertujuan mengantarkan manusia kepada kehidupan yang adil dan sejahtera dan membuat manusia bahagia. Hukum progresif menganut ideologi hukum yang pro keadilan dan hukum yang prorakyat. ${ }^{11}$ Satjipto Rahardjo menggambarkan bahwa hukum selalu dalam proses dengan mengatakan bahwa: hukum adalah institusi yang secara terus menerus membangun dan mengubah dirinya menuju kepada tingkat kesempurnaan yang lebih baik. Kualitas kesempurnaan di sini bisa diverifikasi ke dalam faktor-faktor keadilan, kesejahteraan, kepedulian kepada masyarakat dan lain-lain. Inilah hakikat "hukum selalu dalam proses menjadi" (law as process, law in the making). Hukum tidak ada untuk hukum itu sendiri tetapi untuk manusia. ${ }^{12}$

Penemuan hukum yang progresif secara tegas mengaitkan faktor hukum, kemanusiaan dan moralitas, sehingga penemuan hukum yang dilakukan oleh hakim dalam kerangka menjalankan tugas yudisialnya yang pada akhirnya hakim akan menjatuhkan putusannya. Oleh karena itu, karakter hukum progresif adalah: ${ }^{13}$

1. Penemuan hukum yang didasarkan atas apresiasi hakim sendiri dengan dibimbing oleh pandangannya dan pemikirannya secara mandiri, dengan berpijak pada pandangan bahwa hukum itu ada untuk mengabdi kepada manusia.

2. Penemuan hukum yang bersandarkan pada nilai-nilai hukum, kebenaran dan keadilan serta juga etika dan moralitas.

3. Penemuan hukum yang mampu menciptakan nilai-nilai baru dalam kehidupan masyarakat, atau melakukan rekayasa dalam masyarakat sesuai dengan perkembangan zaman dan teknologi serta keadaan masyarakat. hlm. 6 .

${ }^{11}$ Satjipto Rahardjo, Hukum Progresif Sebuah Sintesa Hukum Indonesia, Genta Publishing, Yogyakarta, 2009,

${ }^{12}$ Satjipto Rahardjo, "Hukum Progresif: Hukum Yang Membebaskan", artikel dalam Jurnal Hukum Progresif, Vol 1/No.1, April 2005, Program Doktor Ilmu Hukum Universitas Diponegoro, 2005, hlm. 6. hlm. 48.

${ }^{13}$ Ahmad Rivai, Penemuan Hukum Oleh Hakim Dalam Perspektif Hukum Progresif, Sinar Grafika, Jakarta, 2010, 
Berangkat dari konsep hukum progresif kewenangan Mahkamah Konstitusi untuk menggali nilai-nilai hukum yang hidup dalam masyarakat yang mencerminkan dinamika nilai keadilan yang terus berkembang sebagaimana telah diamanatkan oleh undang-undang kekuasaan kehakiman. Jadi tidak menutup kemungkinan dua putusan Mahkamah Konstitusi atas hal yang sama berbeda satu dengan yang lain seperti halnya dalam putusan Mahkamah Konstitusi Nomor 4/PUU-VII/2009 tanggal 4 Maret 2009 dengan putusan yang mendahuluinya yaitu putusan nomor 14-17/PUU-V/2007 tanggal 11 Desember 2007. Dalam hal ini putusan Mahkamah Nomor 14-17/PUUV/2007 disempurnakan (tidak dihapus) oleh putusan Mahkamah Konstitusi Nomor 4 /PUU-VII/2009. Dinamika ini sejalan bahwa sifat hukum tersebut dinamis. Hukum harus dapat menyesuaikan dengan perkembangan masyarakat sebagai subjek hukum. Oleh sebab itu hukum harus mampu mengikuti perkembangan masyarakat yang terus berubah. Sejatinya tidak akan mungkin membuat suatu produk hukum yang bertahan secara terus menerus. Hukum yang tidak berubah sedang masyarakat telah berubah hanya akan membuat hukum berada pada ruang hampa dan tidak dapat menyelesaikan persoalan konkret yang ada di dalam masyarakat.

Begitupun hukum pemilihan umum kepala daerah dan pemilihan umum harus mampu dan cepat merespon perubahan masyarakat yang terjadi. Hukum pemilihan umum dan pemilihan kepala daerah cenderung berubah karena bertalian dengan kepentingan politik. Pemilihan kepala daerah dan pemilihan umum tanpa politik tidak akan melahirkan demokrasi. Sebaliknya, politik tanpa pemilihan kepala daerah dan pemilihan umum bukan demokrasi. Pembuatan undang-undang sampai peraturan teknis pelaksanaannya seharusnya memperhatikan perilaku orang-orang yang menjalankannya dan kultur hukum sehingga dimengerti dan dapat dilaksanakan dengan baik dan penuh kesadaran oleh masyarakat. Pelaksanaan hukum yang seperti ini akan menghantarkan masyarakat kepada kesejahteraan, keadilan, kebahagiaan dan kemuliaan.

Dalam perkembangan lembaga penyelenggara pemilu mencoba membatasi khusus pada kejahatan korupsi tidak bisa turut serta kandidat dalam pemilihan umum. Korupsi merupakan faktor penghalang pembangunan ekonomi, sosial, politik dan budaya bangsa. Semangat Undang-Undang No. 31 Tahun 1999, 
Undang-Undang No. 20 Tahun 2001, dan Undang-Undang No. 30 Tahun 2002 tidak terlepas dari semangat dunia internasional yang mencetuskan Declaration of 8 th International Conference Against Corruption tanggal 7-11 September 1977 di Lima yang mencetuskan pemberantasan korupsi secara internasional. Indonesia melakukan ratifikasi United Nations Convention Against Corruption (UNCAC) berdasarkan Resolusi 58/4 tanggal 31 Oktober 2003 sebagaimana ditentukan dalam Undang-Undang Nomor 7 Tahun 2006 tentang Pengesahan Konvensi Perserikatan Bangsa-Bangsa Anti Korupsi 2003. Korupsi merupakan penyalahgunaan jabatan publik untuk kepentingan pribadi. ${ }^{14}$ Selain itu korupsi merupakan tindakan penyalahgunaan yang dilakukan pemerintah. ${ }^{15}$ Korupsi terdiri dari subjek korupsi, motivasi, maksud, cara dan konsekuensi dari perbuatan korupsi yang dilakukan. Korupsi dilakukan dengan menyalahgunakan kekuasaan dan melanggar kode etik yang ada. ${ }^{16}$ Korupsi masuk ke dalam kategori kejahatan yang luar biasa. Korupsi merupakan musuh bersama dan musuh internasional. Korupsi menyebabkan kemiskinan di suatu negara.

Uraian di atas akan mempunyai singgungan dengan upaya perlindungan hak asasi manusia dan semangat kedaulatan rakyat, bahwa setiap orang berhak untuk bergabung dengan atau bersamaan dengan orang lain untuk mendirikan, suatu partai politik atau organisasi untuk maksud bersaing dalam pemilihan. ${ }^{17}$ Demikian pula dengan perintah konstitusi, yaitu kedaulatan berada di tangan rakyat dan dilaksanakan menurut Undang-Undang Dasar. Membatasi hak warga negara Indonesia berstatus mantan narapidana yang merupakan bagian dari rakyat sebagai pemegang kedaulatan pada dasarnya membatasi hak warga negara Indonesia yang ingin memilih dan percaya kepada para mantan terpidana tersebut. Ketentuan tersebut seharusnya diserahkan kepada rakyat sebagai pemegang

\footnotetext{
${ }^{14}$ World Bank: Corruption is the abuse of public power for private benefit. Similar to Corruption is the abuse of public power for private gain. This definition has been used by many scholars on the concept of corruption See, e.g., Olken (2007), Bardhan (2006), Jain (2001), and Rose-Ackerman (2011).

${ }^{15}$ Li, Y.L., Wu, S.J. and Hu, Y.M. (2011), “A Review of Anti-Corruption Studies in Recent Cbina”, artikel dalam Journal Chinese Public Administration 11, page 115-119

${ }^{16}$ He, Z.K. (2003), "Research in the Issues of Corruption and Combationg Corruption during Chinese Transition", artikel dalam Journal Comparative Economic \& Social Systems, 1, page 19-29.

${ }_{17}$ Deklarasi Parlemen Internasional Tentang Kriteria Untuk Pemilihan yang Bebas dan Adil Tahun 1994, Lihat dalam International IDEA, Standar-standar Internasional Pemilihan Umum, Peninjauan Kembali Kerangka Hukum Pemilu, Ibid., hlm. 117-120.
} 
kedaulatan untuk memilih atau tidak memilih para mantan terpidana bukan dengan penentuan persyaratan oleh pembentuk undang-undang. Upaya melakukan pembatasan hak politik melalui penerbitan aturan yang secara hirarkhi lebih rendah dapat dipahami sebagai upaya yang memiliki iktikad baik untuk menjaga proses demokrasi berlangsung secara demokratis. Namun demokrasi tetap mensyaratkan penghormatan terhadap hak asasi manusia. Pelanggaran terhadap hak asasi manusia merupakan pengingkaran konstitusi sehingga terhadap pelanggarnya dapat dimintakan pertanggungjawaban.

Dalam kerangka hak asasi manusia (HAM) Pasal 28I ayat (4) Undang-Undang Dasar menyatakan perlindungan, kemajuan, penegakan, dan pemenuhan hak asasi manusia adalah tanggungjawab negara terutama pemerintah. Dalam UndangUndang Nomor 23 Tahun 1999 tentang Hak Asasi Manusia dalam Pasal 71 yang menyatakan pemerintah wajib dan bertanggungjawab menghormati, melindungi, menegakkan, dan memajukan hak asasi manusia yang diatur dalam undangundang.

Sebagai pemegang kewajiban pemenuhan HAM, negara mengemban tiga tugas antara lain, negara harus menghormati (to respect), melindungi (to protect), dan memenuhi (to fullfil) hak asasi manusia. ${ }^{18}$ Konsepsi HAM dalam perkembangannya sangat terikat dengan konsepsi negara hukum. Dalam sebuah negara hukum sesunguhnya yang memerintah adalah hukum, bukan manusia. Hukum dimaknai sebagai kesatuan hirarkis tatanan norma hukum yang berpuncak pada konstitusi. Hal ini berarti bahwa dalam sebuah negara hukum menghendaki adanya supremasi konstitusi. Supremasi konstitusi di samping merupakan konsekuensi dari konsep negara hukum sekaligus merupakan pelaksanaan demokrasi karena konstitusi merupakan wujud perjanjian sosial tertinggi. ${ }^{19}$ Unsur instrinsik hukum adalah moral berupa perbuatan yang baik dan tidak baik, pantas atau tidak pantas dilakukan. Setiap warga negara yang telah melakukan tindak pidana sepanjang telah menjalankan hukuman yang telah dijatuhkan kepada dirinya maka segala hal yang sebelumnya dicabut akan kembali/pulih dengan sendirinya. Tersisanya hukuman yang bukan merupakan

\footnotetext{
18 Putusan Mahkamah Konstitusi Nomor 42/PUU-XIII/2015, hlm. 14

${ }^{19}$ Jimly Asshiddiqie, Konstitusi...., Op., Cit., hlm. 152-162.
} 
hasil dari putusan hakim tapi muncul karena keinginan sekelompok orang meskipun secara preskriptif bersifat baik namun secara hakiki telah menzalimi rasa keadilan orang lain. Seharusnya upaya perbaikan tersebut muncul melalui pemikiran awal dan lengkap sebelum diberlakukan. Bisa saja dimunculkan melalui perubahan Undang-Undang Nomor 7 Tahun 2017 namun sangat terbuka kemungkinan untuk diuji materi oleh sekelompok orang atau individu yang merasa dirugikan dengan perubahan undang-undang yang akan diberlakukan. Hal ini dikarenakan hukuman tambahan telah dikenakan kepada seseorang yang telah selesai menjalani hukumannya. Penjatuhan hukuman untuk kedua kalinya tidak berdasarkan keputusan pengadilan merupakan pelanggaran hak asasi manusia.

Pemilihan umum merupakan representasi dari demokrasi. Ukuran pemilihan umum yang berintegritas salah satunya adalah (a) penghormatan hak asasi manusia dan perjanjian internasional tentang hak sipil dan politik; (b) terdapat prinsip, standar, hak dan peraturan yang sudah didefinisikan dengan baik yang dilakukan pemerintah untuk mewakili diselenggarakannya pemilu berintegritas; (c) pemerintah bertanggung jawab secara hukum bahwa warga negara setara di mata hukum, legislator dan penegakannya tidak sewenangwenang, dan bahwa hukum menghargai hak asasi manusia. ${ }^{20}$ Penghormatan hak asasi manusia merupakan hal utama dalam demokrasi yang terwujud dalam kegiatan pemilihan umum. Hendaknya hak tersebut tetap kita hormati sepanjang tidak di cabut oleh ketentuan undang-undang dan putusan hakim. Kesimpulan bahwa mantan narapidana sepanjang tidak terdapat putusan hakim yang mengurangi hak politik yang bersangkutan maka secara hukum, dapat mencalonkan diri sebagai calon anggota DPR, DPRD provinsi, dan DPRD kabupaten/kota. Upaya meninjau putusan tetap saja bisa dilakukan namun tetap harus bersifat preskriptif dan tidak berlaku surut sehingga tidak ada pelanggaran hak asasi manusia kepada mantan narapidana.

20 Laporan Dari Komisi Global Untuk Pemilihan Umum, Demokrasi Dan Keamanan, Pendalaman Demokrasi; Strategi Untuk Meningkatkan Integritas Pemilihan Umum di Selurub Dunia, Septemnber 2012, hlm. 6 
Sebagai perbandingan persyaratan calon presiden dan wakil presiden pada Pasal 169 huruf (d) menyatakan bahwa persyaratan calon presiden dan wakil presiden tidak pernah mengkhianati negara serta tidak pernah melakukan tindak pidana korupsi dan tindak pidana berat. Posisi presiden dan wakil presiden tidak sama dengan warga negara lainnya. Posisi tersebut hanya dimiliki oleh 2 orang warga negara saja. Karenanya presiden dan wakil presiden adalah warga negara istimewa. Hal itu terlihat dari perlakuan hukum bila seorang presiden dan wakil presiden di duga melakukan tindak pidana. Presiden tidak dapat diproses seperti layaknya warga negara biasa. Hal itu menunjukkan keistimewaan kedua warga negara tersebut dalam jabatan sebagai presiden dan wakil presiden. Namun dalam hal ini peneliti menyatakan bahwa Pasal 169 huruf (d) mempunyai kelemahan dalam kaitannnya dengan jaminan hak asasi manusia. Hal ini rentan melanggar hak asasi manusia bila terapkan secara serta merta. Setiap orang tidak terkecuali mempunyai kedudukan yang sama di hadapan hukum. Maka setiap warga negara termasuk mantan narapidana sepanjang dan telah menyelesaikan masa hukumannya maka yang bersangkutan akan mempunyai hak yang sama seperti warga negara yang lainnya terkecuali dicabut hak politiknya oleh hakim bahkan untuk seorang presiden dan wakil presiden sekalipun. Hal ini akan menjadi berbeda jika presiden dan wakil presiden pernah melakukan tindakan pengkhianatan kepada negara. Pengkhianatan (aanslag) dapat diterjemahkan langsung sebagai serangan (tindak pidana; kejahatan) yang ditujukan terhadap seseorang (berkedudukan tinggi; kepala negara) ataupun ketika dilekatkan pada pasal-pasal tentang keselamatan negara lebih pada pengertian ikhtiar atau upaya (attempt atau ondernomen). Pemaknaan istilah makar menunjuk kepada kejahatan terhadap keamanan negara dan kejahatan terhadap negara sahabat dan kepala negara sahabat serta wakilnya. ${ }^{21}$

Berkaitan dengan putusan a quo yang memberikan pengampunan terhadap pelaku yang tidak terlibat secara langsung dengan PRRI/Permesta dan GAM dan pihak yang terlibat dalam pemberontakan G.30.S/PKI harus diperhatikan dalam

21 Widati Wulandari dan Tristam P. Moeliono, "Problematika Pengertian Aanslag-Aanslag tot en Feit: Perbandingan Makar dalam KUHP, WvSNI dan Sr", artikel dalam Padjajaran Jurnal Ilmu Hukum Volume 4, Nomor 3, Tahun 2017, hlm. 489-490. 
pembatasan persyaratan seseorang yang akan mencalonkan diri sebagai calon presiden dan wakil presiden. Peran hakim dalam memutus pelaku tindak pidana makar harus melihat peranan masing-masing pelaku tindak pidana makar. ${ }^{22} \mathrm{Hal}$ ini dilakukan agar hakim bisa menentukan seseorang terlibat secara langsung atau tidak langsung terhadap tindakan pengkhianatan terhadap negara. Kehati-hatian ini bertujuan untuk menjamin hak asasi manusia.

Fakta hukum Mahkmah Konstitusi telah memberikan ruang konstitusional kepada mantan narapidana termasuk korupsi ${ }^{23}$ bisa menjadi calon legislatif dalam pemilihan kepala daerah dan pemilihan umum. Meskipun ada penolakan masyarakat pemerhati demokrasi dan pemilu terhadap kekhawatiran mantan narapidana yang ikut dalam kontestasi pemilihan umum tahun 2019. Dalam Pasal 240 ayat (1) huruf (g) Undang-undang Nomor 7 Tahun 2017 tentang Pemilihan Umum menyebutkan persyaratan bakal calon anggota DPR, DPRD provinsi, dan DPRD kabupaten/kota tidak pernah dipidana penjara berdasarkan putusan pengadilan yang telah memperoleh kekuatan hukum tetap karena melakukan tindak pidana yang diancam dengan pidana penjara 5 tahun atau lebih, kecuali secara terbuka dan jujur mengemukakan kepada publik bahwa yang bersangkutan mantan terpidana. Dalam pasal tersebut mantan narapidana (terlepas jenis kejahatannya) dijamin dapat berpartisipasi dalam pemilihan umum sebagai calon anggota DPR, DPRD provinsi, dan DPRD kabupaten/kota terkecuali terdapat putusan hakim yang mengurangi/mencabut hak politik narapidana.

\section{Upaya Membangun Demokrasi Pasca Putusan Mahkamah Konstitusi}

\section{a. Penyelenggara Pemilu (KPU dan Bawaslu)}

Pasca putusan Mahkmah Konstitusi a quo perdebatan legitimasi mantan narapidana sebagai calon anggota legislatif untuk seluruh tingkatan tidak perlu dipersoalkan karena lembaga peradilan sebagai benteng terakhir pencari keadilan telah secara jelas dan nyata memperbolehkan sepanjang memenuhi

${ }^{22}$ Lani Sujiagnes Panjaitan, Alvi Syahrin, Marlina, Jelly Leviza, "Penerapan Hukum Pidana Terhadap Tindak Pidana Makar Oleh Organisasi Papua Merdeka (OPM) Di Kabupaten Jayawijaya (Studi Putusan Nomor 38/Pid.B/2011/PN.Wmn)", artikel dalam USU Law Journal, Vol. 4. No. 3, Juni 2016, hlm. 97

${ }_{23}$ Pendapat kami dalam memahami putusan Mahkamah Konstitusi a quo. 
ketentuan yang telah diputuskan. Perlu pemikiran konstruktif lain untuk memberikan pemahaman demokrasi kepada pemilih daripada membuang energi untuk melakukan perdebatan hukum terhadap suatu keputusan yang telah mempunyai kekuatan hukum yang bersifat final dan mengikat. Putusan Mahkamah Konstitusi harus disikapi secara baik dan taat hukum oleh penyelenggara pemilu khususnya dan masyarakat Indonesia pada umumnya tetap dalam kerangka membangun demokrasi yang konstitusional.

Kerangka hukum mewajibkan badan pelaksana pemilihan umum menjamin penyelenggaraan pemilihan umum berlangsung secara demokratis. Berdasarkan Undang-Undang Nomor 7 Tahun 2017, KPU diberi tugas, wewenang dan kewajiban untuk menyusun dan menetapkan peraturan KPU untuk setiap tahapan pemilu. Wewenang adalah suatu kemampuan yang diberikan oleh peraturan perundang-undangan yang berlaku untuk menimbulkan akibat-akibat hukum. ${ }^{24}$ Wewenang yang dimaksud adalah wewenang yang bersifat atributif.. ${ }^{25}$ Berdasarkan hal tersebut maka KPU sebagai lembaga penyelenggara pemilu mempunyai alas hukum untuk mengeluarkan peraturan teknis yang menjelaskan lebih detail pelaksanaan dari Undang-Undang Nomor 7 Tahun 2017 Pasal 240 ayat (1) huruf (g) tersebut dan peraturan mahkamah a quo.

KPU sebagai penyelenggara pemilu mengeluarkan peraturan teknis pencalonan kepala daerah dan calon legislatif. Bawaslu mempunyai wewenang dalam hal pengawasan calon yang akan berkontestasi dan penerapan peraturan yang terkait. Penyelenggara pemilu harus mampu memanfaatkan wewenang yang dimiliki. Peraturan teknis tersebut harus mengandung ketentuan yang melaksanakan undang-undang dan putusan lembaga peradilan. KPU dapat mengeluarkan ketentuan teknis berupa:

${ }^{24}$ Indroharto, Usaha Memahami Undang-undang Tentang Peradilan Tata Usaha Negara, Pustaka Sinar Harapan, Jakarta, 1991, hlm. 68.

${ }_{25}$ Menurut Philiphus M. Hadjon ada tiga cara memperoleh wewenang yaitu: Atribusi, Delegasi dan Mandat. Atribusi Yakni wewenang untuk membuat keputusan yang langsung bersumber kepada undang-undang dalam arti materil. Atribusi ini juga dikatakan sebagai suatu cara normal untuk memperoleh wewenang pemerintahan. Kewenangan yang diperoleh dari atribusi merupakan kewenangan asli. Kewenangan atributif merupakan kewenangan baru yang sebelumnya kewenangan itu tidak dimiliki oleh organ pemerintahan yang bersangkutan. Lihat dalam Philiphus M. Hadjon, Fungsi Normatif Hukum Administrasi Dalam Mewnjudkan Pemerintahan Yang Bersih (Pidato Pengukuhan Guru Besar dalam Ilmu Hukum Universitas Airlangga, 10 Oktober 1994). Di unduh http://erepo.unud.ac.id/15030/3/0113056142-3-BAB_II.pdf pada tanggal 27 Maret 2018 
1. Ketentuan tentang kewajiban yang harus dilaksanakan pra dan pasca penetapan calon kepala daerah dan calon legislatif yang berstatus mantan narapidana berikut sanksi bila tidak melaksanakan ketentuan secara terbuka dan jujur kepada publik tentang status mantan narapidana.

2. Melakukan sosialisasi tentang calon kepala daerah dan calon legislatif yang turut serta dalam kontestasi termasuk calon berstatus mantan narapidana;

3. Melakukan pendidikan politik kepada pemilih untuk mengetahui visi, misi dan latar belakang calon kepala daerah dan calon legislatif yang berkontestasi.

Upaya yang dapat dilakukan Bawaslu sebagai lembaga pengawas penyelenggaraan pemilu yakni:

1. Mengawasi pelaksanaan peraturan teknis yang berkenaan dengan calon kepala daerah dan calon legislatif yang berstatus mantan narapidana;

2. Mengawasi ketentuan yang wajib dipenuhi oleh calon yang berstatus mantan narapidana;

3. Menjatuhkan sanksi baik kepada KPU dan calon kepala daerah serta calon legislatif yang berstatus mantan narapidana bila melanggar ketentuan undangundang.

Bagi mantan narapidana yang akan turut serta sebagai calon anggota DPR, DPRD propinsi dan DPRD kabupaten/kota dipersyaratkan secara terbuka dan jujur mengemukakan kepada publik bahwa yang bersangkutan mantan terpidana sebagaimana dalam undang-undang a quo. Pemaknaan undang-undang a quo harus dimaknai persyaratan yang harus dilakukan dan dipenuhi sebelum ditetapkan sebagai calon dan setelah ditetapkan sebagai calon anggota DPR, DPRD propinsi dan DPRD kabupaten/kota. Hal ini harus dilakukan secara konkret oleh calon anggota DPR, DPRD propinsi dan DPRD yang berstatus mantan narapidana. Konkret bermakna tidak hanya memenuhi prosedural saja namun secara substansi harus dipenuhi. Kesungguhan menyatakan dirinya sebagai mantan narapidana harus tercermin dalam kampanye visi misi yang bersangkutan. Jujur berarti tidak berbohong, berkata apa adanya. Terbuka dapat dipahami sebagai tidak tertutup dan tidak dirahasiakan. Mekanismenya adalah calon kandidat yang berstatus mantan narapidana setelah ditetapkan dalam daftar 
calon tetap maka dapat ditambahkan klausul atau kalimat yang bersangkutan merupakan mantan narapidana.

Selain itu dalam masa kampanye Komisi Pemilihan Umum (KPU) membuat pengumuman di media cetak daerah atau nasional dan website KPU di seluruh tingkatan masing-masing tentang calon anggota DPR, DPRD propinsi dan DPRD kabupaten/kota yang berstatus mantan narapidana di daerahnya setiap hari selama masa kampanye. Tugas pengumuman ini dapat dilakukan oleh penyelenggara pemilu sesuai tingkatan mantan narapidana terdaftar sebagai calon anggota DPR, DPRD propinsi dan DPRD kabupaten/kota. Hal ini dapat dilakukan oleh KPU karena memiliki dana yang cukup yang bersumber dari anggaran pendapatan dan belanja negara. Kehadiran badan pengawas pemilu dalam melakukan pengawasan terhadap proses ini sangat penting. Ketiadaan pengawasan membuat proses yang sedang dijalankan menjadi lemah. Hal ini dilakukan sebagai upaya untuk memenuhi ketentuan sebagaimana yang dipersyaratkan oleh undang-undang dan memenuhi rasa keadilan masyarakat dan menghilangkan prasangka terhadap penyelenggaraan pemilu yang akan dan/atau sedang dilaksanakan.

\section{b. Partai Politik}

Di lain sisi, pasca Putusan Mahkamah Konstitusi yang memberikan legalitas mantan narapidana dapat berkompetisi sebagai calon kepala daerah dan calon legislatif berada pada partai politik. Proses konstitusional yang dapat dilakukan adalah proses saring partai politik. Partai politik sejatinya menciptakan demokrasi yang berkualitas dan modern yang tidak pernah terpikirkan kecuali muncul dari partai politik. Maju dan mundurnya demokrasi suatu negara berada ditangan partai politik. Peran penting partai politik memiliki dua dimensi, yaitu:26

1. Setelah berhasil mengagregasikan berbagai kepentingan dan nilai yang ada dalam masyarakat, partai politik kemudian mentransformasikannya menjadi sebuah agenda yang dapat dijadikan platform pemilu. Diharapkan platform tersebut mampu menarik banyak suara dari rakyat sehingga partai politik akan mendapatkan banyak kursi di parlemen. Selanjutnya partai politik harus mampu mempengaruhi proses politik dalam legislasi dan implementasi program kebijakan publik itu.

${ }^{26}$ Thomas Meyer, Peran Partai Politik dalam Sebuah Sistem Demokrasi: Sembilan Tesis, Friedrich-Ebert-Stiftung (FES) Kantor Perwakilan Indonesia, Mei 2012, hlm. 28 
2. Partai politik adalah satu-satunya pihak yang dapat menerjemahkan kepentingan dan nilai masyarakat ke dalam legislasi dan kebijakan publik yang mengikat. Hal ini dapat mereka lakukan setelah mereka mendapatkan posisi yang kuat dalam parlemen daerah maupun nasional.

Partai politik mempunyai peluang untuk mencalonkan pasangan yang bersih dan memiliki rekam jejak yang baik. Pencalonan anggota DPR, DPRD provinsi dan DPRD kabupaten/kota merupakan bagian dari rekruitmen politik. Partai politik dapat melakukan pendidikan politik kepada anggotanya. Partai politik dapat membangun sekolah politik untuk menciptakan kader partai yang berintegritas dan profesional. Hal ini dilakukan agar kader partai tersebut mempunyai nilai yang baik di masyarakat sehingga layak berkompetisi. Partai politik menjadi percaya diri untuk mencalonkan calon anggota DPR, DPRD provinsi dan DPRD kabupaten/kota karena bebas persoalan hukum. Hal ini tentunya menguntungkan masyarakat pemilih karena partai politik berhasil menampilkan calon yang berintegritas dan terbebas dari masalah hukum. Ukuran keberhasilan partai politik modern melakukan pendidikan politik bila banyak anggota partai mempunyai daya jual sehingga percaya diri untuk mencalonkan anggotanya sehingga bisa meraup suara dan memperoleh mayoritas kursi legislatif.

\section{c. Lembaga Peradilan}

Upaya membangun demokrasi melalui pemilihan umum yang demokratis memerlukan upaya bersama semua pihak. Aparat penegak hukum dalam hal ini hakim sebagai benteng keadilan mempunyai peran yang sangat besar. Ketentuan dan aturan hukum yang mengatur cara-cara menegakkan hukum dan keadilan harus tersusun dengan baik, benar dan pasti. Kebijaksanaan tidak diperbolehkan bertentangan dengan asas-asas umum pemerintahan yang baik khususnya asas larangan penyalahgunaan wewenang dan asas larangan sewenang-wenang. Selain itu juga tidak boleh bertentangan dengan kepentingan umum. ${ }^{27}$ Pengawasan terhadap institusi peradilan dalam menyelesaikan suatu sengketa hukum dipengadilan perlu dilakukan secara proporsional dan profesional dan

27 Abrori, "Keabsahan Penggunaan Kewenangan Kebebasan Bertindak Bagi Pemerintah (Diskresi): Studi Terhadap Undang-Undang Nomor 30 Tahun 2014 Tentang Administrasi Pemerintahan”, artikel dalam Jurnal Ilmiah Wawasan Insan Akademik, Volume I, Nomor 1, Mei 2016, hlm. 10. 
memperhatikan budaya masyarakat yang terkait proses hukum harus memahami posisi dan kedudukannya sebagai elemen terpenting bagi tegaknya hukum dan keadilan. ${ }^{28}$

Menjaga dan mewujudkan suatu putusan hakim yang adil dan mendapat respon yang penuh kedamaian dari para pencari keadilan harus memperhatikan dua aspek penting yaitu terkait dengan tata cara penegakan hukum (prosedural justice) dan ini hasil dari penegakan hukum itu sendiri (substantive justice). Prosedural justice berkaitan dengan aspek kepastian hukum dalam proses penegakan hukum di pengadilan dan substantive justice terkait dengan putusan pengadilan atau hakim yang dapat menghilangkan gap antara keadilan individual dengan keadilan sosial dengan cermat diletakkan nilai-nilai sosial atau moral dari setiap aturan hokum, dengan kata lain dalam setiap keadilan individual akan terkandung keadilan sosial. Harmoni antara keadilan sosial dan individual yang diterapkan melalui putusan pengadilan tentu dapat menghadirkan suasana kedamaian bagi masyarakat pencari keadilan. ${ }^{29}$

Standar internasional berkenaan penyelenggaraan pemilu yang demokratis yang disusun oleh The Organization of Democratic Institution and Human Rights (ODIHR)-(OSCE) dan The Institute for Democracy and Electoral Assistance (IDEA) menyatakan pembatasan atau pengekangan hak untuk memberikan suara diperbolehkan dengan catatan pembatasan dan pengekangan itu secara jelas dibenarkan oleh keadaan-keadaan atau didasarkan atas norma-norma yang telah diakui. ${ }^{30}$ Berdasarkan rumusan standar internasional tersebut bahwa pengecualian hak memilih dan dipilih diakui sebagai bagian dari penyelenggaraan pemilu yang demokratis. Terhadap hal ini hakim dapat melakukan terobosan hukum sebagai benteng terakhir keadilan. Korupsi uang negara di Indonesia merupakan kejadian yang sangat luar biasa dan telah menjadi budaya yang dilakukan masyarakat dari level bawah sampai pada level atas. Untuk itu harapan kepada hakim sangat tinggi

${ }^{28}$ Ismail Rumadan, "Peran Lembaga Peradilan Sebagai Institusi Penegak Hukum Dalam Menegakkan Keadilan Bagi Terwujudnya Perdamaian”, artikel dalam Jurnal Rechtvinding, Volume 6, Nomor 1, April 2017, hlm. 85-86.

${ }^{29} \mathrm{Ibid}$

${ }^{30}$ IDEA, Standar-standar International Pemilihan Umum, Peninjanan Kembali Kerangka Hukum Pemilu, Seri Buku Panduan International Institute for Democracy and Electoral Assistance (International IDEA). Lihat juga IDEA, kerangka Hukum Pemilu Indonesia, Edisi Kedua, International Institute for Democracy and Electoral Assistance, 2003 
untuk membuat jera para pelaku tindak pidana korupsi. Sudah saatnya setiap pelaku tindak pidana korupsi wajib dijatuhi pidana tambahan berupa pencabutan hak politik permanen sehingga pihak yang akan melakukan tindak pidana korupsi akan berpikir untuk tidak melakukan perbuatan tersebut. Sehingga persoalan calon kandidat dalam pemilihan kepala daerah dan pemilihan umum terbebas dari mantan narapidana korupsi akan gugur dengan sendirinya.

\section{Penutup}

Putusan Mahkamah Konstitusi menjamin hak konstitusional mantan narapidana untuk turut serta sebagai kandidat kepala daerah dan calon legislatif dalam pemilihan kepala daerah dan pemilihan umum. Putusan tersebut memberikan legalitas kepada mantan narapidana untuk menduduki jabatanjabatan publik yang dipilih (elected officials) sepanjang tidak dijatuhi pidana tambahan berupa pencabutan hak pilih oleh putusan pengadilan yang telah mempunyai kekuatan hukum. Putusan Mahkamah Konstitusi ini wajib dimaknai sebagai sumber hukum yang bersifat final dan mengikat oleh penyelenggara pemilu yang bersifat mengatur bukan membatasi hak asasi manusia.

Upaya penyelenggara pemilu membangun demokrasi harus dipandang sebagai iktikad baik dalam rangka menjamin penyelenggaraan pemilihan kepala daerah dan berlangsung secara demokratis. Upaya tersebut dilakukan dengan mengeluarkan peraturan teknis pelaksana untuk melaksanakan putusan Mahkamah Konstitusi sebagaimana dipersyaratkan a quo. Materi peraturan tersebut harus mencantumkan sanksi tegas kepada mantan narapidana yang tidak memenuhi ketentuan dalam peraturan tersebut baik pra dan pasca penetapan sebagai kepala daerah dan calon anggota DPR, DPRD provinsi dan DPRD kabupaten/kota. Bawaslu sebagai lembaga pengawas pemilu harus mengawasi proses pencalonan kepala daerah dan calon legislatif agar sesuai ketentuan peraturan perundang-undangan yang berlaku. Partai menjadi penentu utama suksesnya penyelenggaran pemilu dan pemilihan kepala daerah yang demokratis. Partai politik mempunyai peranan penting dalam menghasilkan calon anggota DPR, DPRD provinsi dan DPRD kabupaten/kota yang profesional dan berintegritas. Kesalahan dalam menempatkan calon yang akan berkompetisi akan 
membawa citra buruk terhadap partai politik pengusung. Hal ini dapat dilakukan dengan melakukan pengkaderan yang baik dan pendidikan politik berjenjang yang harus menjadi bagian yang tidak terpisahkan dari keberadaan partai politik.

\section{Daftar Pustaka}

\section{Buku}

Amiruddin dan Zainal Asikin, Pengantar Metode Penelitian Hukum, Rajawali Pers, Jakarta, 2014.

Asshiddiqie, Jimly, Konstitusi \& Konstitusionalisme Indonesia, Edisi Revisi, Konstitusi Press, Jakarta, 2005.

Gagasan Kedaulatan Rakyat Dalam Konstitusi Dan Pelaksanaannya Di Indonesia, PT Ichtiar Baru Van Hoeve, Jakarta, 1994.

IDEA, Kerangka Hukum Pemilu Indonesia, Edisi Kedua, 2003.

_. Standar-standar Internasional Pemilihan Umum, Peninjauan Kembali Kerangka Hukum Pemilu, 1994.

Indroharto, Usaha Memahami Undang-undang Tentang Peradilan Tata Usaha Negara, Pustaka Sinar Harapan, Jakarta, 1991.

Meyer, Thomas, Peran Partai Politik dalam Sebuah Sistem Demokrasi: Sembilan Tesis, Friedrich-Ebert-Stiftung (FES) Kantor Perwakilan Indonesia, Mei 2012.

Rahardjo, Satjipto, Hukum Progresif Sebuah Sintesa Hukum Indonesia, Genta Publishing, Yogyakarta, 2009 , Membedah Hukum Progresif, Penerbit Buku Kompas., 2008.

Rahayu, Hukum Hak Asasi Manusia, Edisi Revisi 2015, Badan Penerbit Universitas Diponegoro Semarang, 2015.

Rivai, Ahmad, Penemuan Hukum Oleh Hakim Dalam Perspektif Hukum Progresif, Sinar Grafika, Jakarta, 2010.

Suseno, Franz Magnis, Etika Politik, Gramedia Pustaka Utama, Jakarta, 2001.

Jurnal

Abrori, "Keabsahan Penggunaan Kewenangan Kebebasan Bertindak Bagi Pemerintah (Diskresi): Studi Terhadap Undang-Undang Nomor 30 Tahun 2014 Tentang Administrasi Pemerintahan", artikel dalam Jurnal korupsillmiah Wawasan Insan Akademik, Volume I, Nomor 1; Mei 2016.

Aedi, Ahmad Ulil, "Rekonstruksi Asas Kesamaan di Hadapan Hukum (Equality Before The Law) (Suatu Kajian Khusus Putusan Mahkamah Konstitusi Perkara 21-22/PUU-V/2007 Dalam Perspektif Filsafat Hukum", artikel dalam Jurnal Law Reform, Vol. 8, No. 2, Tahun 2013. 
He, Z.K., "Research in the Issues of Corruption and Combationg Corruption during Chinese Transition", artikel dalam Journal Comparative Economic \& Social Systems, 1, 2003.

Li, Y.L., Wu, S.J. and Hu, Y.M., "A Review of Anti-Corruption Studies in Recent China", artikel dalam Journal Chinese Public Administration, 11, 2011.

Panjaitan, Lani Sujiagnes, Alvi Syahrin, Marlina, Jelly Leviza, “Penerapan Hukum Pidana Terhadap Tindak Pidana Makar Oleh Organisasi Papua Merdeka (OPM) Di Kabupaten Jayawijaya (Studi Putusan Nomor 38/Pid.B/2011/PN.Wmn)", artikel dalam USU Law Journal, Vol. 4 No. 3 Juni 2016.

Rahardjo, Satjipto, "Hukum Progresif: Hukum Yang Membebaskan”, artikel dalam Jurnal Hukum Progresif, Vol 1/No. 1, April 2005, Program Doktor Ilmu Hukum Universitas Diponegoro, 2005.

Rumadan, Ismail, "Peran Lembaga Peradilan Sebagai Institusi Penegak Hukum Dalam Menegakkan Keadilan Bagi Terwujudnya Perdamaian", artikel dalam Jurnal Rechtvinding, Volume 6, Nomor 1, April 2017.

Sulaeman, Affan, "Demokrasi, Partai Politik, Dan Pemilihan Kepala", artikel dalam Jurnal Ilmu Pemerintahan D CosmoGov, Vol. 1 No. 1, April 2015.

Wulandari, Widati dan Tristam P. Moeliono, "Problematika Pengertian AanslagAanslag tot en Feit: Perbandingan Makar dalam KUHP, WvSNI dan Sr", artikel dalam Padjajaran Jurnal Ilmu Hukum Volume 4 Nomor 3 Tahun 2017.

\section{Peraturan Perundang-undangan}

Undang-Undang Dasar Negara Republik Indonesia Tahun 1945.

Undang-Undang Nomor 7 Tahun 2017 tentang Pemilihan Umum

Putusan Mahkamah Konstitusi Nomor 14-17/PUU-V/2007 tanggal 11 Desember 2007.

Putusan Mahkamah Konstitusi nomor 42/PUU-XIII/2015.

\section{Internet}

Philiphus M. Hadjon, Fungsi Normatif Hukum Administrasi Dalam Mewujudkan Pemerintahan Yang Bersih (Pidato Pengukuhan Guru Besar dalam Ilmu Hukum Universitas Airlangga, 10 Oktober 1994). Di unduh http:/ / erepo.unud.ac.id/15030/3/0113056142-3-BAB_II.pdf pada tanggal 27 Maret 2018.

Dylan Aprialdo Rachman, "KPU tidak Perlu Mundur Soal Larangan mantan Koruptor Jadi Caleg 2019", https://nasional.kompas.com/read/2018/ 04/17/11333141/kpu-tidak-perlu-mundur-soal-larangan-mantankoruptor-jadi-caleg-2019 di akses tanggal 24 April 2018. 